Article

\title{
Enhypyrazinones A and B, Pyrazinone Natural Products from a Marine-Derived Myxobacterium Enhygromyxa sp.
}

\author{
Fan Zhang ${ }^{1}$, Doug R. Braun ${ }^{1}$, Scott R. Rajski ${ }^{1}$ (D), Don DeMaria ${ }^{2}$ and Tim S. Bugni ${ }^{1, *(D)}$ \\ 1 Pharmaceutical Sciences Division, University of Wisconsin-Madison, Madison, WI 53705, USA; \\ fzhang83@wisc.edu (F.Z.); drbraun1@wisc.edu (D.R.B.); scott.rajski@wisc.edu (S.R.R.) \\ 2 Sea Samples, 369 Westshore Drive, Summerland Key, FL 33042, USA; dondemaria@aol.com \\ * Correspondence: tim.bugni@wisc.edu; Tel.: +1-608-263-2519
}

Received: 20 November 2019; Accepted: 10 December 2019; Published: 12 December 2019

\begin{abstract}
To date, studies describing myxobacterial secondary metabolites have been relatively scarce in comparison to those addressing actinobacterial secondary metabolites. This realization suggests the immense potential of myxobacteria as an intriguing source of secondary metabolites with unusual structural features and a wide array of biological activities. Marine-derived myxobacteria are especially attractive due to their unique biosynthetic gene clusters, although they are more difficult to handle than terrestrial myxobacteria. Here, we report the discovery of two new pyrazinone-type molecules, enhypyrazinones A and B, from a marine-derived myxobacterium Enhygromyxa sp. Their structures were elucidated by HRESIMS and comprehensive NMR data analyses. Compounds 1 and 2, which contain a rare trisubstituted-pyrazinone core, represent a unique class of molecules from Enhygromyxa sp.
\end{abstract}

Keywords: pyrazinone; marine-derived myxobacterium; Enhygromyxa sp.

\section{Introduction}

Myxobacteria are Gram-negative gliding bacteria with large genomes; these organisms also undergo complex multicellular developmental processes that lead to fruiting body formation [1]. Most myxobacteria have a heterotrophic lifestyle and feed on different bacteria and fungi through assorted predatory behaviors [2]. Compared to their non-predatory relatives, predatory myxobacteria possess a higher density of secondary metabolite gene clusters in their genomes; this suggests their great promise as repositories for the discovery of novel natural products [3]. Terrestrial myxobacteria usually do not tolerate $\mathrm{NaCl}$ concentrations greater than $1.0 \%$, and before 2005 the vast majority of characterized myxobacteria were obtained from terrestrial habitats. Recently, however, four new genera of halotolerant and obligate marine myxobacteria, Enhygromyxa, Haliangium, Plesiocystis, and Pseudenhygromyxa, have been discovered and classified [4-9]. Although not extensively studied, the limited records of marine-derived myxobacteria indicate their immense potential as prolific producers of novel natural compounds with prominent biological activities, making these social microbes highly attractive for drug discovery [10-16]. The genus Enhygromyxa, in particular, has been shown to produce novel bioactive molecules, including salimabromide [17], salimyxins A and B [18], enhygrolides A and B [18], enhygromic acid [19], and deoxyenhygrolides A and B (Figure 1) [19]. 


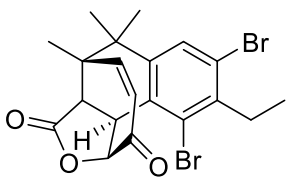

salimabromide

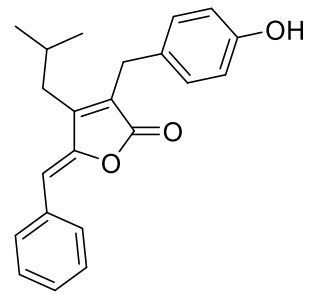

enhygrolide $A(R=O H)$ deoxyenhygrolide $A(R=H)$

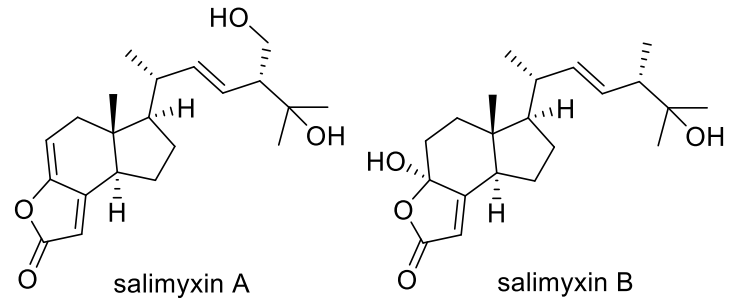<smiles>CC(C)CC1=C(Cc2ccccc2)OC(=O)O/C1=C\c1ccc(O)cc1</smiles>

enhygrolide $B(\mathrm{R}=\mathrm{OH})$ deoxyenhygrolide $B(R=H)$

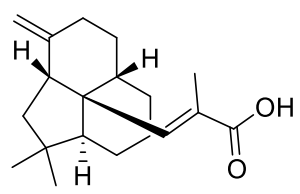

enhygromic acid

Figure 1. Secondary metabolites from Enhygromyxa spp.

In our efforts to explore the potential of myxobacteria as a source of unique unknown natural products, we isolated a marine myxobacterium from the sponge Biemna sp., which was identified as Enhygromyxa sp. WMMC2659 by $16 \mathrm{~S}$ sequence analysis. Metabolomics-guided fractionation of strain WMMC2695 led to the discovery of two new pyrazinone derivatives, termed here as enhypyrazinones A (1) and B (2) in Figure 2.

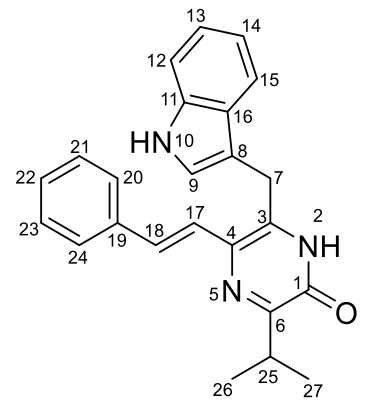

1<smiles>CC(C)c1nc(/C=C\c2ccccc2)c(Cc2c[nH]c3ccccc23)[nH]c1=O</smiles>

2

Figure 2. Two new pyrazinone derivatives: enhypyrazinones A (1) and B (2).

\section{Results}

\subsection{Cultivation Conditions of Marine-Derived Myxobacterium Enhygromyxa sp. WMMC2695}

Marine myxobacteria are particularly rare and difficult to handle, because their nutritional and metabolic growth requirements are in most cases not well understood, and need to be determined on a case-by-case basis for each strain. Until now, only a few isolates could be cultured under laboratory conditions. Unlike faster-growing microbes, nutrient-lean media are preferable for marine myxobacteria as they enable the germination of myxospores, and later support swarming of the vegetative cells [20]. Based on previous reports about conditions for isolation and cultivation of Enhygromyxa spp., Escherichia coli $[17,18]$, half-strength yeast cell VB12 medium (VY/2) [4,19], half-strength VY/2 (VY/4) [17,19], and one-third-strength casitone yeast extract medium (1/3 CY) [4] can be used to provide nutrition for the growth of Enhygromyxa spp. Therefore, several media conditions including living E. coli, dead E. coli, $\mathrm{VY} / 2, \mathrm{VY} / 4, \mathrm{CY}, 1 / 3 \mathrm{CY}$, and 1/6 CY were tested for the growth of WMMC2659. R2A agar was also included as one of the testing media due to our experiences with other halotolerant myxobacterial isolates. WMMC2659 was found to be cultivable only on living and dead E. coli DH5 $\alpha$, while casitone-containing media seemed to inhibit the growth of WMMC2659 (Table 1). Furthermore, the 
growth of WMMC2659 on autoclaved E. coli DH5 $\alpha$ was substantially impaired compared to similar systems employing live cells. More importantly, comparisons of the LC-MS analyses of the culture extract from WMMC2659 (living E. coli DH5 $\alpha$ as media) and that of E. coli DH5 $\alpha$ (Figure 3) clearly indicated that WMMC2659 produced two metabolites when using E. coli $\mathrm{DH} 5 \alpha$ as nutrition.

Table 1. Tested media conditions for Enhygromyxa sp. WMMC2659.

\begin{tabular}{ccccccccc}
\hline Media & E. coli & Dead E. coli & VY/2 & VY/4 & CY & 1/3 CY & 1/6 CY & R2A \\
\hline Growth & Yes & Yes & No & No & No & No & No & No \\
\hline
\end{tabular}

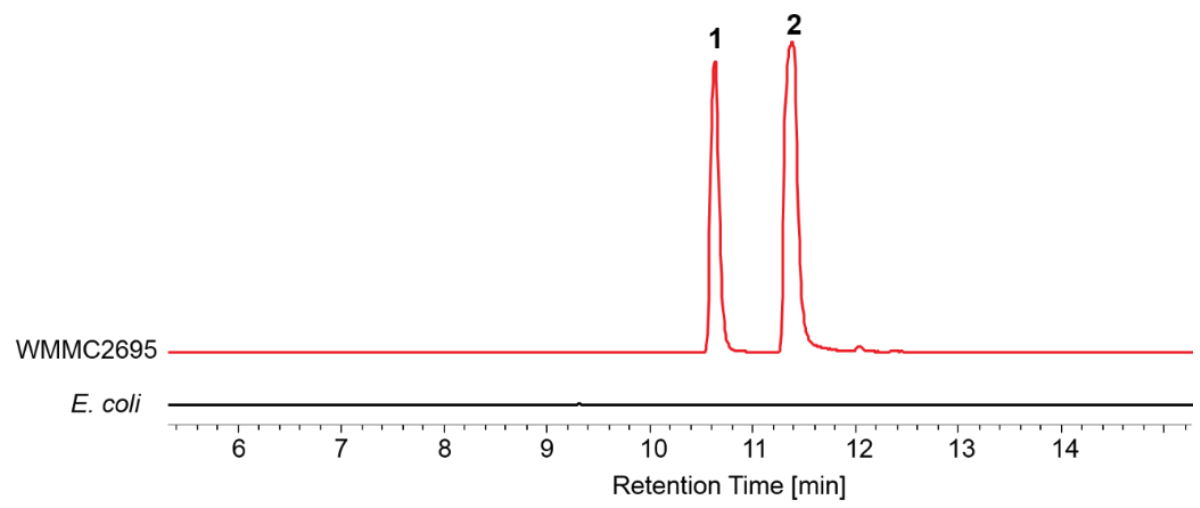

Figure 3. Extracted ion chromatogram (EIC) traces $(m / z$ 392) of the culture extracts from WMMC2659 (living Escherichia coli $\mathrm{DH} 5 \alpha$ as media) and E. coli $\mathrm{DH} 5 \alpha$.

\subsection{Structure Elucidation of Enhypyrazinones $A$ and $B$}

The molecular formula of enhypyrazinone $\mathrm{A}(\mathbf{1})$ was determined to be $\mathrm{C}_{24} \mathrm{H}_{23} \mathrm{~N}_{3} \mathrm{O}$ on the basis of the HRESIMS data $\left([\mathrm{M}+\mathrm{Na}]^{+}, \mathrm{m} / z\right.$ 392.1736), indicating 15 degrees of unsaturation. Analysis of the ${ }^{1} \mathrm{H}$ and ${ }^{13} \mathrm{C}$ NMR and HSQC spectra (Table 2) revealed the presence of eight non-protonated $\mathrm{sp}^{2}$-type carbons, 12 olefin/aromatic protons, one methine, one methylene, and two methyl groups. The presence of five aromatic protons at $\delta_{\mathrm{H}} 7.51(\mathrm{H}-20 / 24), 7.32(\mathrm{H}-21 / 23)$ and $7.20(\mathrm{H}-22)$, together with COSY correlations among these aromatic protons (Figure 4), suggested a mono-substituted benzene ring. The HMBC correlations from $\mathrm{H}-17$ and $\mathrm{H}-18$ to $\mathrm{C}-19$ suggested that an olefin was attached to the mono-substituted benzene ring via C-19. Additionally, COSY and ${ }^{1} \mathrm{H}-{ }^{13} \mathrm{C}$ HMBC spectra of 1 revealed a typical 3-substituted indole alkaloid moiety [21] with signals at $\delta_{\mathrm{H}} 7.22(\mathrm{H}-9), 11.0(\mathrm{NH}-10), 7.33$ (H-12), 7.05 (H-13), 6.97 (H-14), 7.65 (H-15), and $\delta_{\mathrm{C}} 111.1$ (C-8), 123.6 (C-9), 136.2 (C-11), 111.6 (C-12), 121.1 (C-13), 118.5 (C-14), 118.6 (C-15), 126.7 ppm (C-16). Additionally, HMBC correlations from $\mathrm{H}_{2}-7$ to $\mathrm{C}-8, \mathrm{C}-9$, and $\mathrm{C}-16$ suggested linkage of the methylene to the indole moiety via C-8. In addition, $\mathrm{HMBC}$ correlations from $\mathrm{H}-17$ and $\mathrm{H}-18$ to $\mathrm{C}-4$, and from $\mathrm{H}_{2}-7$ to $\mathrm{C}-3$, indicated the linkages between C-17 and C-4, and between C-7 and C-3, respectively. The COSY correlations between the two methyl groups $\left(\mathrm{H}_{3}-26\right.$ and $\left.\mathrm{H}_{3}-27\right)$ and the methine (H-25) established the isopropyl spin system, and HMBC correlations from $\mathrm{H}-25, \mathrm{H}_{3}-26$, and $\mathrm{H}_{3}-27$ to $\mathrm{C}-6$ located the isopropyl group at C-6. Although three substructures were deduced, four non-protonated carbons (C-1, C-3, C-4, and C-6), two nitrogens, and one oxygen remained unaccounted for. Therefore, the ${ }^{1} \mathrm{H}-{ }^{15} \mathrm{~N}$ HMBC spectrum was used to unambiguously complete the elucidation of compound 1 . The cross-peaks for $\mathrm{H}-25$ and $\mathrm{H}-17$ with N-5 indicated that the linkage between C-4 and C-6 involved N-5 (Figure 4). The HMBC correlations from $\mathrm{H}_{2}-7$ to $\mathrm{C}-4$ and $\mathrm{N}-2$ revealed that $\mathrm{C}-3$ was attached to $\mathrm{C}-4$ and N-2. An additional HMBC correlation from $\mathrm{H}-25$ to $\mathrm{C}-1$ indicated the connection between C-6 and C-1. Lastly, the carbonyl carbon $\mathrm{C}-1\left(\delta_{\mathrm{C}}\right.$ 156.3) was attached to $\mathrm{N}-2$ to form an $\alpha, \beta$-unsaturated amide, thus illustrating the presence of a pyrazinone core. The remaining exchangeable proton was assigned as 2-NH to satisfy the molecular formula. On the basis of the large vicinal ${ }^{1} \mathrm{H}-{ }^{1} \mathrm{H}$ coupling constants $(J=15.5 \mathrm{~Hz})$, the 
alkene (H-17, H-18) configuration was assigned as $E[22,23]$. Taken together, the structure of 1 was therefore established.
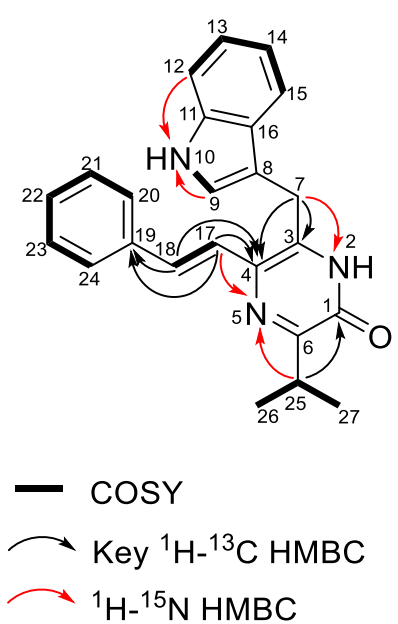

Figure 4. Key 2D NMR correlations for compound 1.

Table 2. ${ }^{1} \mathrm{H}$ and ${ }^{13} \mathrm{C}$ NMR Data for Enhypyrazinone A (1) $\left(600 \mathrm{MHz}\right.$ for ${ }^{1} \mathrm{H}, 125 \mathrm{MHz}$ for ${ }^{13} \mathrm{C}$, DMSO- $\left.d_{6}\right)$.

\begin{tabular}{|c|c|c|c|c|c|c|}
\hline Position & $\delta_{C}$, mult. & $\delta_{\mathrm{H}}(J$ in $\mathrm{Hz})$ & $\cos Y$ & ${ }^{1} \mathrm{H}-{ }^{13} \mathrm{C} \mathrm{HMBC}^{\mathrm{a}}$ & $\delta_{N}{ }^{b}$ & ${ }^{1} \mathrm{H}-{ }^{15} \mathrm{~N}$ HMBC ${ }^{\mathrm{c}}$ \\
\hline 1 & $156.3, \mathrm{C}$ & & & & & \\
\hline 2 & & & & & 187.3 & \\
\hline 3 & $137.3, \mathrm{C}$ & & & & & \\
\hline 4 & $126.5, \mathrm{C}$ & & & & & \\
\hline 5 & & & & & 323.2 & \\
\hline 6 & 159.0, C & & & & & \\
\hline 7 & $25.6, \mathrm{CH}_{2}$ & $4.14, \mathrm{~s}$ & 9 & $3,4,8,9,16$ & & 2 \\
\hline 8 & $111.1, \mathrm{C}$ & & & & & \\
\hline 9 & 123.6, CH & $7.22, \mathrm{~s}$ & 7 & $8,11,16$ & & 10 \\
\hline 10 & & $11.0, \mathrm{~s}$ & 9 & & 132.0 & \\
\hline 11 & $136.2, \mathrm{C}$ & & & & & \\
\hline 12 & 111.6, $\mathrm{CH}$ & $7.33, \mathrm{~d}(8.0)$ & 13 & 14,16 & & 10 \\
\hline 13 & 121.1, CH & $7.05, \mathrm{t}(8.0)$ & & 11,15 & & \\
\hline 14 & $118.5, \mathrm{CH}$ & $6.97, \mathrm{t}(8.0)$ & 15 & 12,16 & & \\
\hline 15 & 118.6, CH & $7.65, \mathrm{~d}(8.0)$ & 14 & $8,11,13,16$ & & \\
\hline 16 & 126.7, C & & & & & \\
\hline 17 & $123.1, \mathrm{CH}$ & $7.42, \mathrm{~d}(15.5)$ & & 4,19 & & 5 \\
\hline 18 & $126.2, \mathrm{CH}$ & 7.24, d (15.5) & & $4,19,20,24$ & & \\
\hline 19 & $137.5, \mathrm{C}$ & & & & & \\
\hline 20 & $126.3, \mathrm{CH}$ & $7.51, \mathrm{~d}(7.7)$ & 21 & 22,24 & & \\
\hline 21 & $128.7, \mathrm{CH}$ & $7.32, \mathrm{t}(7.7)$ & 20,22 & 19,23 & & \\
\hline 22 & 127.0, CH & $7.20, \mathrm{t}(7.7)$ & 21,23 & 20,24 & & \\
\hline 23 & $128.7, \mathrm{CH}$ & $7.32, \mathrm{t}(7.7)$ & 22,24 & 19,21 & & \\
\hline 24 & $126.3, \mathrm{CH}$ & $7.51, \mathrm{~d}(7.7)$ & 23 & 20,22 & & \\
\hline 25 & $29.7, \mathrm{CH}$ & $3.30, \mathrm{~m}$ & 26,27 & $1,6,26,27$ & & 5 \\
\hline 26 & $20.2, \mathrm{CH}_{3}$ & $1.19, \mathrm{~d}(6.8)$ & 25 & $6,25,27$ & & \\
\hline 27 & $20.2, \mathrm{CH}_{3}$ & $1.19, \mathrm{~d}(6.8)$ & 25 & $6,25,26$ & & \\
\hline
\end{tabular}

${ }^{\mathrm{a}} \mathrm{HMBC}$ correlations are from proton(s) to the indicated carbon. ${ }^{\mathrm{b}}$ The chemical shifts of ${ }^{15} \mathrm{~N}$ were determined by ${ }^{1} \mathrm{H}-{ }^{15} \mathrm{~N}$ HMBC, and the chemical shifts of ${ }^{15} \mathrm{~N}$ were referenced to liquid $\mathrm{NH}_{3}$ (under pressure) at $25{ }^{\circ} \mathrm{C}$ by the NMR software TopSpin. ${ }^{\mathrm{c}} \mathrm{HMBC}$ correlations are from proton(s) to the indicated nitrogen.

Enhypyrazinone B (2) was found to have the same molecular formula $\left(\mathrm{C}_{24} \mathrm{H}_{23} \mathrm{~N}_{3} \mathrm{O}\right)$ as $\mathbf{1}$ on the basis of HRESIMS data. Unfortunately, DMSO- $d_{6}$ was a poor NMR solvent for compound 2 (Figures S14-S19), and thus a different NMR solvent system $\left(\mathrm{CDCl}_{3} / \mathrm{CD}_{3} \mathrm{OD} 1: 1\right)$ was used for NMR studies of 2 (Figures S8-S12). Interpretation of 1D and 2D NMR data sets suggested that 2 is a stereoisomer of $\mathbf{1}$. A relatively small coupling constant $(J=12 \mathrm{~Hz})$ between $\mathrm{H}-17$ and $\mathrm{H}-18$ indicated that the geometry of the alkene (H17, H18) was Z [22,23], thereby enabling unambiguous assignment of the structure for $\mathbf{2}$. All other data supported this conclusion. 


\subsection{Bioactivity Testing}

Compounds 1 and 2 were tested for antibacterial activity against E. coli (ATCC 25922), methicillin-resistant Staphylococcus aureus (MRSA; ATCC 33591), and methicillin-sensitive Staphylococcus aureus (MSSA; ATCC 29213) in disk diffusion assays; only weak activity against MSSA was noted. To gain more accurate antimicrobial bioactivity data for compounds $\mathbf{1}$ and $\mathbf{2}$, we determined minimum inhibitory concentration (MIC) values for each species against MSSA. Notably, both $\mathbf{1}$ and $\mathbf{2}$ were characterized by MIC values $>128 \mu \mathrm{g} / \mathrm{mL}$, consistent with very low antibacterial activities. Compounds 1 and $\mathbf{2}$ do not appear to exert antimicrobial effects that clearly benefit the producer, since E. coli DH5 $\alpha$ was used to provide nutrition for WMMC2659. Moreover, $\mathbf{1}$ and $\mathbf{2}$ are more easily and economically biosynthesized than larger signaling peptides, and thus might have a function related to myxobacterial intra- and extra-species cell-cell interaction.

\section{Discussion}

In conclusion, two pyrazinone-type metabolites, $\mathbf{1}$ and $\mathbf{2}$, were isolated from a marine-derived myxobacterium Enhygromyxa sp. Notably, this is the first report of natural products generated from this bacterial genus under fermentation conditions involving myxobacterial predation and feeding on a different bacterium (E. coli DH5 $\alpha$ ). Compounds $\mathbf{1}$ and $\mathbf{2}$ contain a rare trisubstituted pyrazinone core, and only a few metabolites bearing this moiety have been reported so far. The most related pyrazinone derivatives are tyrvalin and phevalin, from a pathogenic Staphylococcus aureus strain [24,25]; leuvalin, which was found in pathogenic strains of S. aureus, S. epidermidis, S. capitis, and S. lugdunensis [26]; arglecin, argvalin, JBIR-56, and JBIR-57 from Streptomyces sp. [27,28]; sorazinone B, which was from Nannocystis pusilla strain MNa10913 [29]; as well as butrepyrazinone, from a Ghanaian Verrucosispora sp. K51G [30]. In most cases, the C-4 of the pyrazinone ring is unsubstituted. It appears that the pyrazinones are generated by multidomain non-ribosomal peptide synthetase (NRPS) assembly line systems. Notably, for the systems examined thus far, it appears that cleavage from the NRPS proceeds via thioester reduction; this affords a $C$-terminal aldehyde upon which the $N$-terminal amino group condenses to afford an imine; ultimately, oxidation of this newly formed heterocycle affords $2(1 \mathrm{H})$-pyrazinones [25]. For previously reported pyrazinone-producing microbes, the typical absence of a substituent at C-4 is logical given its aldehydic oxidation state following dipeptide liberation from the NRPS machinery [24-30]. In the case of $\mathbf{1}$ and $\mathbf{2}$, it is presently unclear precisely how C-4 comes to be the attachment point for the cinnamoyl moiety, although this question is currently under investigation.

\section{Materials and Methods}

\subsection{General Experimental Procedures}

UV spectra were recorded on an Aminco/OLIS UV-Vis Spectrophotometer (Bogart, GA, USA). IR spectra were measured with a Bruker Equinox 55/S FT-IR Spectrophotometer (Santa Barbara, CA, USA). Both 1D and 2D NMR spectra were obtained using a Bruker Avance $500 \mathrm{MHz}$ spectrometer (Billerica, MA, USA) with ${ }^{1} \mathrm{H}\left\{{ }^{13} \mathrm{C} /{ }^{15} \mathrm{~N}\right\}$ cryoprobe and a $500 \mathrm{MHz}$ spectrometer with ${ }^{13} \mathrm{C} /{ }^{15} \mathrm{~N}\left\{{ }^{1} \mathrm{H}\right\}$ cryoprobe; chemical shifts were referenced to the residual solvent peaks $\left(\mathrm{CD}_{3} \mathrm{OD}: \delta_{\mathrm{H}}=3.31, \delta_{\mathrm{C}}=49.15\right.$; DMSO- $d_{6}$ : $\left.\delta_{\mathrm{H}}=2.50, \delta_{\mathrm{C}}=39.51\right)$. HRMS data were acquired with a Bruker MaXis $4 \mathrm{G}$ QTOF mass spectrometer (Billerica, MA, USA). RP HPLC was performed using a Shimadzu Prominence HPLC system and a Phenomenex Luna $\mathrm{C}_{18}$ column $(250 \times 10 \mathrm{~mm}, 5 \mu \mathrm{m})$ (Torrance, CA, USA).

\subsection{Biological Material}

WMMC2659 was isolated from the sponge Biemna sp. which was collected in the Florida Keys, USA (24 39.393, -81 26.268) on August 13th, 2014. A voucher specimen of the sponge is housed at the University of Wisconsin-Madison. WMMC2659 was isolated using the baiting technique as described by lizuka et al. [5e], only ground sponge was used in place of soil. WMMC2659 was maintained at 28 ${ }^{\circ} \mathrm{C}$ on plates containing $50 \%$ artificial seawater (ASW) with $1.5 \%$ agar streaked with E. coli DH5 $\alpha$ on the 
surface as the food source. Artificial seawater solutions I (415.2 $\mathrm{g} \mathrm{NaCl}, 69.54 \mathrm{~g} \mathrm{Na}_{2} \mathrm{SO}_{4}, 11.74 \mathrm{~g} \mathrm{KCl}$, $\left.3.40 \mathrm{~g} \mathrm{NaHCO}_{3}, 1.7 \mathrm{~g} \mathrm{KBr}, 0.45 \mathrm{~g} \mathrm{H}_{3} \mathrm{BO}_{3}, 0.054 \mathrm{~g} \mathrm{NaF}\right)$ and II $\left(187.9 \mathrm{~g} \mathrm{MgCl}_{2} \cdot 6 \mathrm{H}_{2} \mathrm{O}, 22.72 \mathrm{~g} \mathrm{CaCl}_{2} \cdot 2 \mathrm{H}_{2} \mathrm{O}\right.$, $0.428 \mathrm{~g} \mathrm{SrCl}_{2} \cdot 6 \mathrm{H}_{2} \mathrm{O}$ ) were made up separately and combined to give a total volume of $20 \mathrm{~L}$.

\subsection{Sequencing}

The 16S rRNA gene was amplified using colony PCR with the primers 8-27F ( $5^{\prime}$ to $3^{\prime}$ GAGTTTGATCCTGGCTCAG) and 1492R (5' to $3^{\prime}$ GGTTACCTTGTTACGACTT). The following PCR conditions were used: $94{ }^{\circ} \mathrm{C}$ for $5 \mathrm{~min}$, followed by 35 cycles of $94{ }^{\circ} \mathrm{C}$ for $30 \mathrm{~s}, 55^{\circ} \mathrm{C}$ for $1 \mathrm{~min}$, $72{ }^{\circ} \mathrm{C}$ for $1.5 \mathrm{~min}$, with a final step of $72{ }^{\circ} \mathrm{C}$ for $5 \mathrm{~min}$. The PCR bands were excised from the gel and purified using the QIAquick Gel Extraction kit (QIAGEN, Germantown, MD, USA). Sanger sequencing was performed at the UW Biotechnology Center. WMMC2695 was identified as an Enhygromyxa sp. The $16 \mathrm{~S}$ sequence for WMMC2695 was deposited in GenBank (accession number MN657412).

\subsection{Fermentation, Extraction, and Isolation}

A starter culture was prepared by scraping fruiting bodies off of a petri dish and inoculating them into a $125 \mathrm{~mL}$ Erlenmeyer flask containing 1-2 g of washed living E. coli DH5 $\alpha$ in $25 \mathrm{~mL} \mathrm{50 \%} \mathrm{ASW}$ buffered with HEPES ( $25 \mathrm{mM}, \mathrm{pH} 7.8)$. When the culture showed orange coloration, it was inoculated into $1 \mathrm{~L}$ of ASW containing 30-35 g living E. coli DH5 $\alpha$, cyanocobalamin $(0.5 \mathrm{mg})$, Diaion HP20 (7\% by weight) and buffered with HEPES ( $25 \mathrm{mM}, \mathrm{pH} 7.8)$. The culture was shaken at $200 \mathrm{rpm}$ at $28^{\circ} \mathrm{C}$ for 9 days before extraction. Living E. coli DH5 $\alpha$ was prepared by growing overnight cultures in $2 \times T Y$ and washing them 3 times with sterile MilliQ water. Filtered HP20 was washed with distilled $\mathrm{H}_{2} \mathrm{O}$ and extracted with acetone. The acetone extract $(2.0 \mathrm{~g})$ was subjected to liquid-liquid partitioning using $30 \%$ aqueous $\mathrm{CH}_{3} \mathrm{OH}$ and $\mathrm{CHCl}_{3}$ (1:1). The $\mathrm{CHCl}_{3}$-soluble partition $(0.2 \mathrm{~g})$ was fractionated by Sephadex LH20 column chromatography $\left(\mathrm{CHCl}_{3}: \mathrm{CH}_{3} \mathrm{OH}, 1: 1\right)$. The fractions containing 1 and 2 were further subjected to RP HPLC ( $45 \% / 55 \%$ to $90 \% / 10 \% \mathrm{CH}_{3} \mathrm{OH}-\mathrm{H}_{2} \mathrm{O}$ over $26 \mathrm{~min}, 4.0 \mathrm{mg} / \mathrm{mL}$ ) using a Phenomenex Luna $\mathrm{C}_{18}$ column $(250 \times 10 \mathrm{~mm}, 5 \mu \mathrm{m})$, yielding $1\left(5.5 \mathrm{mg}, t_{\mathrm{R}} 22.2 \mathrm{~min}\right)$ and $2(1.5 \mathrm{mg}$, $\left.t_{\mathrm{R}} 19.2 \mathrm{~min}\right)$.

\subsection{Spectral Data of Compounds $\mathbf{1}$ and 2}

Enhypyrazinone A (1): yellow powder; $\mathrm{UV}\left(\mathrm{CH}_{3} \mathrm{OH} / \mathrm{CHCl}_{3} 1: 1\right) \lambda_{\max }(\log \varepsilon) 315$ (3.88) nm; IR (ATR) $v_{\max } 3363.9,2945.3,2834.3,1736.9,1639.2,1449.9,1409.6,1217.0,1115.3,1020.0 \mathrm{~cm}^{-1},{ }^{1} \mathrm{H}$ and ${ }^{13} \mathrm{C}$ NMR (See Table 2); HRESIMS m/z 392.1736 [M + Na] $]^{+}$(calcd. for $\mathrm{C}_{24} \mathrm{H}_{23} \mathrm{~N}_{3} \mathrm{ONa}^{+}$, 392.1733).

Enhypyrazinone B (2): yellow powder; $\mathrm{UV}\left(\mathrm{CH}_{3} \mathrm{OH} / \mathrm{CHCl}_{3}\right.$ 1:1) $\lambda_{\max }(\log \varepsilon) 290$ (3.89) nm; IR (ATR) $v_{\max } 3341.0,2944.4,2832.5,1737.6,1641.7,1449.1,1229.0,1116.2,1022.9 \mathrm{~cm}^{-1} ;{ }^{1} \mathrm{H}$ and ${ }^{13} \mathrm{C} \mathrm{NMR}$ (See Table S1); HRESIMS m/z $392.1735[\mathrm{M}+\mathrm{Na}]^{+}$(calcd. for $\mathrm{C}_{24} \mathrm{H}_{23} \mathrm{~N}_{3} \mathrm{ONa}^{+}$, 392.1733).

\subsection{Media Recipe for Other Tested Conditions for the Growth of Enhygromyxa sp. WMMC2659}

VY/2 medium contains $5.0 \mathrm{~g}$ Baker's yeast cake, $0.5 \mathrm{mg}$ cyanocobalamin per liter with $50 \%$ ASW. $\mathrm{VY} / 4$ medium is half-strength VY/2 per liter with $50 \%$ ASW. CY medium contains 3.0 g casitone, 1.0 g yeast extract per liter with $50 \%$ ASW. $1 / 3 \mathrm{CY}$ and 1/6 CY media are one-third-strength and one-sixth-strength CY medium per liter with $50 \%$ ASW, respectively. R2A medium contains $0.5 \mathrm{~g}$ yeast extract, $0.5 \mathrm{~g}$ peptone, $0.5 \mathrm{~g}$ casamino acids, $0.5 \mathrm{~g}$ dextrose, $0.5 \mathrm{~g}$ soluble starch, $0.3 \mathrm{~g}$ sodium pyruvate, $0.3 \mathrm{~g}$ dipotassium phosphate, $0.05 \mathrm{~g}$ magnesium phosphate per liter with $50 \%$ ASW.

\subsection{Antibacterial Assays}

Compounds 1 and 2 were tested for antibacterial activity against E. coli (ATCC 25922), MRSA (ATCC 33591), and MSSA (ATCC 25913) in disk diffusion assays. Five microliters (10 mg/mL) of each compound was used for each disk, and only a $1 \mathrm{~cm}$ inhibition zone was observed against MSSA for both compounds $\mathbf{1}$ and $\mathbf{2}$. MICs were further determined using a dilution antimicrobial susceptibility 
test for MSSA [31]. Compounds 1 and 2 were dissolved in DMSO, serially diluted to 10 concentrations $(0.25-128 \mu \mathrm{g} / \mathrm{mL})$, and tested in a 96-well plate. Vancomycin was used as the positive control against MSSA, which showed a MIC of $1 \mu \mathrm{g} / \mathrm{mL}$. Compounds 1, 2, and the positive control were tested in duplicate. Eight untreated media controls were included on each plate. The plates were incubated at $33^{\circ} \mathrm{C}$ for $18 \mathrm{~h}$. The MIC was determined as the lowest concentration that inhibited visible growth of bacteria.

Supplementary Materials: The following are available online at http:/www.mdpi.com/1660-3397/17/12/698/s1, Figure S1: ${ }^{1} \mathrm{H}$ NMR spectrum of enhypyrazinone A $\left(\mathbf{1} ; 600 \mathrm{MHz}\right.$, DMSO- $\left.d_{6}\right)$, Figure S2: ${ }^{13} \mathrm{C}$ NMR spectrum of enhypyrazinone A $\left(\mathbf{1} ; 125 \mathrm{MHz}\right.$, DMSO- $\left.d_{6}\right)$, Figure S3: gCOSY spectrum of enhypyrazinone A $(\mathbf{1} ; 600 \mathrm{MHz}$, DMSO- $\left.d_{6}\right)$, Figure S4: gHSQC spectrum of enhypyrazinone A $\left(1 ; 600 \mathrm{MHz}\right.$, DMSO- $\left.d_{6}\right)$, Figure S5: gHMBC spectrum of enhypyrazinone A $\left(\mathbf{1} ; 600 \mathrm{MHz}\right.$, DMSO- $\left.d_{6}\right)$, Figure $\mathrm{S6}:{ }^{1} \mathrm{H}^{-15} \mathrm{~N}$ HMBC spectrum of enhypyrazinone A $\left(\mathbf{1} ; 600 \mathrm{MHz}\right.$, DMSO- $\left.d_{6}\right)$, Figure S7: Positive ion HRESIMS of enhypyrazinone A (1), Figure S8: ${ }^{1} \mathrm{H}$ NMR spectrum of enhypyrazinone $\mathrm{B}\left(2 ; 500 \mathrm{MHz}, \mathrm{CDCl}_{3} / \mathrm{CD}_{3} \mathrm{OD} 1: 1\right)$, Figure S9: ${ }^{13} \mathrm{C}$ NMR spectrum of enhypyrazinone $\mathrm{B}(2 ; 125$ $\left.\mathrm{MHz}, \mathrm{CDCl}_{3} / \mathrm{CD}_{3} \mathrm{OD} 1: 1\right)$, Figure S10: gCOSY spectrum of enhypyrazinone B $\left(2 ; 500 \mathrm{MHz}, \mathrm{CDCl}_{3} / \mathrm{CD}_{3} \mathrm{OD} 1: 1\right)$, Figure S11: gHSQC spectrum of enhypyrazinone $\mathrm{B}\left(2 ; 500 \mathrm{MHz}, \mathrm{CDCl}_{3} / \mathrm{CD}_{3} \mathrm{OD} 1: 1\right)$, Figure S12: gHMBC spectrum of enhypyrazinone $\mathrm{B}\left(2 ; 500 \mathrm{MHz}, \mathrm{CDCl}_{3} / \mathrm{CD}_{3} \mathrm{OD} 1: 1\right)$, Figure $\mathrm{S} 13:{ }^{1} \mathrm{H}^{-15} \mathrm{~N}$ HMBC spectrum of enhypyrazinone $\mathrm{B}$ (2; $\left.500 \mathrm{MHz}, \mathrm{CDCl}_{3} / \mathrm{CD}_{3} \mathrm{OD} 1: 1\right)$, Figure S14: ${ }^{1} \mathrm{H}$ NMR spectrum of enhypyrazinone B (2; $\left.500 \mathrm{MHz}, \mathrm{DMSO}-d_{6}\right)$, Figure S15: ${ }^{13} \mathrm{C}$ NMR spectrum of enhypyrazinone B $\left(2 ; 125 \mathrm{MHz}\right.$, DMSO- $\left.d_{6}\right)$, Figure S16: gCOSY spectrum of enhypyrazinone B $\left(2 ; 500 \mathrm{MHz}\right.$, DMSO- $\left.d_{6}\right)$, Figure S17: gHSQC spectrum of enhypyrazinone B $(2 ; 500 \mathrm{MHz}$, DMSO- $\left.d_{6}\right)$, Figure S18: gHMBC spectrum of enhypyrazinone B (2; $500 \mathrm{MHz}$, DMSO- $\left.d_{6}\right)$, Figure S19: ${ }^{1} \mathrm{H}^{-}{ }^{15} \mathrm{~N} \mathrm{HMBC}$ spectrum of enhypyrazinone B $\left(2 ; 500 \mathrm{MHz}\right.$, DMSO- $\left.d_{6}\right)$, Figure S20: Positive ion HRESIMS of enhypyrazinone B (2), Table S1: ${ }^{1} \mathrm{H}$ and ${ }^{13} \mathrm{C}$ NMR data for enhypyrazinone B (2) $\left(500 \mathrm{MHz}\right.$ for ${ }^{1} \mathrm{H}, 125 \mathrm{MHz}$ for ${ }^{13} \mathrm{C}, \mathrm{CDCl}_{3} / \mathrm{CD}_{3} \mathrm{OD}$ $1: 1)$.

Author Contributions: Conceptualization, F.Z. and T.S.B.; methodology, F.Z. and D.R.B.; validation, F.Z. and D.R.B.; formal analysis, F.Z.; investigation, F.Z. and D.R.B.; resources, F.Z., D.R.B. and D.D.; data curation, F.Z.; writing — original draft preparation, F.Z.; writing — review and editing, S.R.R. and T.S.B.; visualization, F.Z.; supervision, T.S.B.; project administration, T.S.B.; funding acquisition, T.S.B.

Funding: This project was funded by the University of Wisconsin-Madison School of Pharmacy, and the National Institutes of Health grants U19AI109673 and U19AI142720.

Acknowledgments: This work was supported by funding from the University of Wisconsin-Madison School of Pharmacy. This work was also funded by the National Institutes of Health grants U19AI109673 and U19AI142720. We thank the Analytical Instrumentation Center (AIC) at the University of Wisconsin-Madison School of Pharmacy for the facilities to acquire spectroscopic data, especially MS data. This study made use of the National Magnetic Resonance Facility at Madison (NMRFAM), which is supported by NIH grants P41RR02301 (BRTP/NCRR) and P41GM66326 (NIGMS)).

Conflicts of Interest: The authors declare no conflict of interest.

\section{References}

1. Claessen, D.; Rozen, D.E.; Kuipers, O.P.; Sogaard-Andersen, L.; van Wezel, G.P. Bacterial solutions to multicellularity: A tale of biofilms, filaments and fruiting bodies. Nat. Rev. Microbiol. 2014, 12, 115-124. [CrossRef] [PubMed]

2. Yao, Y.; Wei, X.; Ebright, R.; Wall, D. Antibiotic production by myxobacteria plays a role in predation. J. Bacteriol. 2011, 193, 4626-4633.

3. Korp, J.; Vela Gurovic, M.S.; Nett, M. Antibiotics from predatory bacteria. Beilstein J. Org. Chem. 2016, 12, 594-607. [CrossRef] [PubMed]

4. Iizuka, T.; Jojima, Y.; Fudou, R.; Tokura, M.; Hiraishi, A.; Yamanaka, S. Enhygromyxa salina gen. nov., sp. nov., a slightly halophilic myxobacterium isolated from the coastal areas of Japan. Syst. Appl. Microbiol. 2003, 26, 189-196. [CrossRef]

5. Iizuka, T.; Jojima, Y.; Hayakawa, A.; Fujii, T.; Yamanaka, S.; Fudou, R. Pseudenhygromyxa salsuginis gen. nov., sp. nov., a myxobacterium isolated from an estuarine marsh. Int. J. Syst. Evol. Microbiol. 2013, 63, 1360-1369. [CrossRef]

6. Iizuka, T.; Jojima, Y.; Fudou, R.; Hiraishi, A.; Ahn, J.W.; Yamanaka, S. Plesiocystis pacifica gen. nov., sp. nov., a marine myxobacterium that contains dihydrogenated menaquinone, isolated from the Pacific coasts of Japan. Int. J. Syst. Evol. Microbiol. 2003, 53, 189-195. [CrossRef] 
7. Li, Y.Z.; Hu, W.; Zhang, Y.Q.; Qiu, Z.; Zhang, Y.; Wu, B.H. A simple method to isolate salt-tolerant myxobacteria from marine samples. J. Microbiol. Methods 2002, 50, 205-209. [CrossRef]

8. Fudou, R.; Jojima, Y.; lizuka, T.; Yamanaka, S. Haliangium ochraceum gen. nov., sp. nov. and Haliangium tepidum sp. nov.: Novel moderately halophilic myxobacteria isolated from coastal saline environments. J. Gen. Appl. Microbiol. 2002, 48, 109-115. [CrossRef]

9. Iizuka, T.; Jojima, Y.; Fudou, R.; Yamanaka, S. Isolation of myxobacteria from the marine environment. FEMS Microbiol. Lett. 1998, 169, 317-322. [CrossRef]

10. Wenzel, S.C.; Müller, R. The impact of genomics on the exploitation of the myxobacterial secondary metabolome. Nat. Prod. Rep. 2009, 26, 1385-1407. [CrossRef] [PubMed]

11. Müller, R.; Wink, J. Future potential for anti-infectives from bacteria-how to exploit biodiversity and genomic potential. Int. J. Med. Microbiol. 2014, 304, 3-13. [CrossRef] [PubMed]

12. Schäberle, T.F.; Lohr, F.; Schmitz, A.; König, G.M. Antibiotics from myxobacteria. Nat. Prod. Rep. 2014, 31 , 953-972. [CrossRef] [PubMed]

13. Herrmann, J.; Fayad, A.A.; Müller, R. Natural products from myxobacteria: Novel metabolites and bioactivities. Nat. Prod. Rep. 2017, 34, 135-160. [CrossRef]

14. Weissman, K.J.; Müller, R. Myxobacterial secondary metabolites: Bioactivities and modes-of-action. Nat. Prod. Rep. 2010, 27, 1276-1295. [CrossRef] [PubMed]

15. Gemperlein, K.; Zaburannyi, N.; Garcia, R.; La Clair, J.J.; Müller, R. Metabolic and biosynthetic diversity in marine myxobacteria. Mar. Drugs 2018, 16, 314. [CrossRef]

16. Amiri Moghaddam, J.; Crüsemann, M.; Alanjary, M.; Harms, H.; Dávila-Céspedes, A.; Blom, J.; Poehlein, A.; Ziemert, N.; König, G.M.; Schäberle, T.F. Analysis of the genome and metabolome of marine myxobacteria reveals high potential for biosynthesis of novel specialized metabolites. Sci. Rep. 2018, 8, 16600. [CrossRef]

17. Felder, S.; Dreisigacker, S.; Kehraus, S.; Neu, E.; Bierbaum, G.; Wright, P.R.; Menche, D.; Schaberle, T.F.; Konig, G.M. Salimabromide: Unexpected chemistry from the obligate marine myxobacterium Enhygromxya salina. Chem. Eur. J. 2013, 19, 9319-9324. [CrossRef]

18. Felder, S.; Kehraus, S.; Neu, E.; Bierbaum, G.; Schaberle, T.F.; Konig, G.M. Salimyxins and enhygrolides: Antibiotic, sponge-related metabolites from the obligate marine myxobacterium Enhygromyxa salina. ChemBioChem 2013, 14, 1363-1371. [CrossRef]

19. Tomura, T.; Nagashima, S.; Yamazaki, S.; Iizuka, T.; Fudou, R.; Ojka, M. An unusual diterpene-enhygromic acid and deoxyenhygrolides from a marine myxobacterium, Enhygromyxa sp. Mar. Drugs 2017, 15, 109. [CrossRef]

20. Albataineh, H.; Stevens, D.C. Marine myxobacteria: A few good halophiles. Mar. Drugs 2018, 16, 209. [CrossRef]

21. Li, C.; Gloer, J.B.; Wicklow, D.T. Thiersindoles A-C: New indole diterpenoids from Penicillium thiersii. J. Nat. Prod. 2003, 66, 1232-1235. [CrossRef] [PubMed]

22. Hoshino, S.; Okada, M.; Wakimoto, T.; Zhang, H.; Hayashi, F.; Onaka, H.; Abe, I. Niizalactams A-C, multicyclic macrolactams isolated from combined culture of Streptomyces with mycolic acid-containing bacterium. J. Nat. Prod. 2015, 78, 3011-3017. [CrossRef] [PubMed]

23. Xu, L.; Wu, P.; Wright, S.J.; Du, L.; Wei, X. Bioactive polycyclic tetramate macrolactams from Lysobacter enzymogenes and their absolute configurations by theoretical ECD calculations. J. Nat. Prod. 2015, 78, 1841-1847. [CrossRef] [PubMed]

24. Wyatt, M.A.; Wang, W.; Roux, C.M.; Beasley, F.C.; Heinrichs, D.E.; Dunman, P.M.; Magarvey, N.A. Staphylococcus aureus nonribosomal peptide secondary metabolites regulate virulence. Science 2011, 329, 294-296. [CrossRef] [PubMed]

25. Zimmermann, M.; Fischbach, M.A. A family of pyrazinone natural products from a conserved nonribosomal peptide synthetase in Staphylococcus aureus. Chem. Biol. Brief. Commun. 2010, 17, 925-930. [CrossRef]

26. Wyatt, M.A.; Mok, M.C.; Junop, M.; Magarvey, N.A. Heterologous expression and structural characterisation of a pyrazinone natural product assembly line. ChemBioChem 2012, 13, 2408-2415. [CrossRef]

27. Alvarez, M.E.; White, C.B.; Gregory, J.; Kydd, G.C.; Harris, A.; Sun, H.H.; Gillum, A.M.; Cooper, R. Phevalin, a new calpain inhibitor, from a Streptomyces sp. J. Antibiot. 1995, 48, 1165-1167. [CrossRef]

28. Motohashi, K.; Inaba, K.; Fuse, S.; Doi, T.; Izumikawa, M.; Khan, S.T.; Takagi, M.; Takahashi, T.; Shin-ya, K. JBIR-56 and JBIR-57, 2(1H)-pyrazinones from a marine sponge-derived Streptomyces sp. SpD081030SC-03. J. Nat. Prod. 2011, 74, 1630-1635. [CrossRef] 
29. Jansen, R.; Sood, S.; Mohr, K.I.; Kunze, B.; Irschik, H.; Stadler, M.; Müller, R. Nannozinones and sorazinones, unprecedented pyrazinones from myxobacteria. J. Nat. Prod. 2014, 77, 2545-2552. [CrossRef]

30. Kyeremeh, K.; Acquah, K.S.; Camas, M.; Tabudravu, J.; Houssen, W.; Deng, H.; Jaspars, M. Butrepyrazinone, a new pyrazinone with an unusual methylation pattern from a Ghanaian Verrucosispora sp. K51G. Mar. Drugs 2014, 12, 5197-5208. [CrossRef]

31. Wikler, M.A.; Cockerill, F.R.; Craig, W.A.; Dudley, M.N.; Eliopoulos, G.M.; Low, M.D.; Sheehan, D.J.; Tenover, F.C.; Turnidge, J.D.; Weinstein, M.P.; et al. National Committee for Clinical Laboratory Standards. In Methods for Dilution Antimicrobial Susceptibility Tests for Bacteria that Grow Aerobically; Approved Standard, 7th ed.; NCCLS: Villanova, PA, USA, 2006; Volume 26, pp. M7-A7.

C 2019 by the authors. Licensee MDPI, Basel, Switzerland. This article is an open access article distributed under the terms and conditions of the Creative Commons Attribution (CC BY) license (http://creativecommons.org/licenses/by/4.0/). 